\title{
Building The Character Of The Millennial Generation In Revolution 5.0 To Realize The Unity Of The Indonesian Nation
}

\author{
Hadi Karyono $^{1 *}$, Hudi Karno Sabowo ${ }^{2}$, Sri Hartati ${ }^{3}$ \\ 1,2,3 Faculty of Law, University of 17 August 1945 Semarang, Indonesia \\ * Corresponding author: \\ Email: karyonohadi08@gmail.com
}

\begin{abstract}
.
Building the character of millennials in the era of revolution 5.0 in filling independence is an obligation as a large-populated country such as the Unitary State of the Republic of Indonesia. In facing it, it is necessary to prepare a resilient and characterful generation facing the challenges in revolution 5.0, which is growing at this time, namely applying Pancasila values for the younger generation that can be implemented in the right momentum. In reality, some young people are now damaged by morals because of various things that affect them. Influences include the adverse effects of globalization, friends, increasingly sophisticated electronic media, drugs, liquor, and other harmful things. This research aims to direct the younger generation in building the nation. Research methods using literature studies are data collection techniques by conducting study studies of books, literature, and others. The results of this research confirm that the younger generation at the time of revolution 5.0 still needs direction and understanding in the life of the nation and state. The conclusion is that the younger generation, as the holder of the leadership relay, needs to be equipped with a national character with Pancasila spirit. So that the relay of the continuity of the nation to be maintained by the republic will be the unity and unity of the country and the realization of our national goals.
\end{abstract}

Keywords: Millenial generation, Revolution 5.0, National unity

\section{INTRODUCTION}

A state formed undoubtedly has a purpose and purpose, as well as the state of Indonesia or often referred to as the Unitary State of the Republic of Indonesia, the Unitary State of the Republic of Indonesia is the largest archipelagic country in the world, consisting of 17,504 islands. The name of the Republic of Indonesia is often referred to as Nusantara, with a population of nearly 270,054,853 people in 2018 [1]. It is the fourth most populous country globally and the country with the largest Muslim population of more than 230 million [2]. The composition of the largest population is in the productive age, namely millennials with 69.38 million or $25.87 \%$ and Generation $\mathrm{X} 58.65$ million or $21.88 \%$. With such a large population, it is necessary to prepare to form a strong and characterized generation [3]; as a bulwark in facing challenges in the current era of growing globalization, the younger generation is the cadre who will lead the Indonesian nation in the future [4]. In the hands of young people, the baton of leadership of the Indonesian country lies. They are the ones who will lead and determine the Indonesian nation in a better direction [5]. 
To become a more developed, civilized, and competitive country among countries.Building a generation of character requires character education for this millennial generation [6]. This era is characterized by the ease with which people get information from various parts of the world due to the rapid development of technology [7]. This condition not only contributes positively to a particular nation or social aggregate but also has an unconstructive impact [8]Today, many young people are morally damaged because of various things that affect them. Because of the adverse effects of globalization, friends get along with increasingly sophisticated electronic media, drugs, liquor, and other harmful things [9]. Such circumstances are very concerning and need special attention because they are the next generation of the nation who will continue the struggles of old age to build the Indonesian government [10].

One of the threats of the younger generation in this millennial era is the emergence of radicalism groups that participate in piggybacking on reform euphoria that is full of freedom with its political agenda to shift the ideology of Pancasila into a caliphate, according to data there are $9 \%$ of Indonesians who disagree with Pancasila. This value continues to grow because some people do not understand the importance of Pancasila because of the influence of radical movements in society. While according to the Alvatara Research survey there are $19.4 \%$ of civil servants indicated anti-Pancasila, there are even $23 . \%$ of students agreed to jihad to establish an Islamic State, then $23.3 \%$ of high school students agree with the same. To restore the character of the younger generation, commonly called the millennial generation, so as not to be exposed to radicalism, it is necessary to build the character of the resilient millennial generation. How to create the feeling of millennials in the era of revolution 5.0 to realize the social justice of the Indonesian nation, in this paper, the author takes the theme.

\section{METHODS}

This research was conducted in a literature study and field observation. Study the library of data collection techniques by studying various books, literature, notes, and reports that have to do with the problem solved. Furthermore, to get evident characteristics of discourse in the form of theories and concepts studied, the author uses content analysis, a research technique to make inferences that can be replicated, and valid data by paying attention to the context.

\section{RESULT AND DISCUSSION}

Researchers made observations in several areas such as the campus environment, cafes where people or students hang out around the city of Semarang. In the observations of the researchers, the attitudes seen in some people and students show attitudes that have not applied the values of Pancasila in everyday life [11]. Among them are as follow's : 
a. In the first precept it is stated "Belief in One Supreme God". When observed, there are still a lot of people and students who do not carry out their obligations to worship as religious people. When the Dzuhur call to prayer sounded, there were still many people who remained at the hangout location even until the Asr call to prayer sounded, it was very clear that this person was indeed intending to leave his worship obligations. Not only that, in other cities there are also several Islamic groups that formed and divided the life of the nation and state.

b. The second precept reads "Just and Civilized Humanity". When gathered in a community together in one place still shows an individual attitude. Where each is only focused on the gadgets they have. Even though there are friends beside them, they still play gadgets like they don't care about the people around them. Then it also often happens, a group that does not defend what is right actually defends what is wrong because the group mates involved made a mistake.

c. In the third precept it says "Indonesian Unity". In mid-2019, there were riots among Papuan students in Malang who demanded independence for Papua. Which should have been done in a good manner by going to the government, not by carrying out violent actions in areas that are not where they belong.

d. In the fourth precept, it is stated "Democracy Led by Wisdom of Wisdom in Representative Deliberation". The visible attitude is not respecting other people's opinions when discussing because they think their opinions are correct and other people's opinions are not appropriate, refuse to attend when invited to a meeting by the organization, force other people's choices in general elections.

e. In the fifth precept, it is stated "Social Justice for All Indonesian People". For this precept, very many attitudes appear to be not applied. Namely the attitude of favoritism in social interactions, which group each other and choose to make friends. Then the sense of mutual cooperation is fading, violating traffic rules, groups destroying public facilities, littering, committing acts of money corruption and not wanting to cooperate when friends need help.

From the five precepts that have been described above, it is clear that the attitudes that people take in everyday life do not apply the Pancasila values that have been upheld in Indonesia [12]. Therefore, it is necessary to replant the values of Pancasila in the millennial generation [13].

There are three levels of values in the Pancasila ideology, namely basic values, instrumental values, and practical values [14]. The three values are explained as follows:

a. Basic value, a value that is abstract and fixed, independent of the influence of changes in time. Basic values are principles, which are abstract and general, not bound by time and place. The basic values of Pancasila grew well from the history of the struggle of the Indonesian nation against the invaders who had afflicted the Indonesian people, in addition to the ideals of the nation who were oppressed by the colonialists. 
b. Instrumental values, contextual values. Instrumental value is the elaboration of Pancasila values, which is the direction of performance for a certain period of time and under certain conditions. Instrumental values can be adapted to the demands of the times. However, the instrument value must refer to the basic value described. From their value content, instrumental values are policies, strategies, organizations, systems, plans, programs, and even projects that follow up on these basic values. The state institutions authorized to compile instrumental values are the MPR, the President, and the DPR.

c. Practical values, values found in everyday life. In the form of how the Indonesian people practice the values of Pancasila.

Practical values are many forms of application of Pancasila values, both written and unwritten; both from the executive, legislative, judicial branches; by community organizations, economic bodies, community leaders, even by individual citizens[12].Building the character of the millennial generation is very closely related to how character education will be given, the definition of character education is "an effort to educate children so that they can make wise decisions and practice in everyday life, so that they can make a positive contribution to their environment. Another opinion about character education is "a conscious and planned effort in knowing the truth or goodness, loving and doing it in everyday life" Character comes from values about something. A value that is manifested in the form of a child's behavior is called character. Therefore, a child who is still innocent will often follow the behavior of his parents or playmates, even his caregiver. Closely related to this problem, a psychologist argues that character is different from personality, because personality is a trait that is innate, in other words, personality is genetic.

The opinion above can be emphasized that character building is the formation of a personality that arises from within the child who violates the norms that apply in society so that it disturbs the peace of the surrounding community. Character coherently radiates from the results of thought, heart, sports, as well as the feelings and intentions of a person or group of people. Character is a characteristic of a person or group of people that contains values, abilities, certainty, moral capacity, and resilience in the face of difficulties and challenges. Ron Kurtus, the founder of the "School of Champion" Educational Site, argues that character is a set of behavior or behavior (behavior) of a person so that from his behavior, people will know "what he is like". According to him, character will determine a person's ability to achieve his goals effectively, the ability to be honest and frank with others and the ability to obey existing rules and regulations. Some of the characters we already know include hottempered, shy, liar, honest, envious, hypocritical, helpful, patient, religious, materialistic, selfish, generous, arrogant, quiet, responsible, shameless, obedient, authoritarian, compassionate, vindictive, self-conscious and so on. Character is formed from the process of imitation, namely through the process of seeing, hearing and following, then the real character can be taught intentionally. Therefore, a child can 
have a good character or a bad cha racter depending on the source he is studying or the source that teaches him

\section{a. Character Building Goals}

The purpose of character building is very closely related to the ideals to be realized, for example we will create a young generation who is intelligent in the fields of science and technology (science and technology) and is commendable in their faith and piety (imtak), so now is the time for academic benches to provide education. "character" to students, namely "character building curriculum". There are several objectives associated with the formation and education of character in campus or education as follows:[15]

a. Strengthen and develop the values of life that are considered important and necessary so that they become the distinctive personality/ownership of students as the values developed.

b. Correcting the behavior of students who are not in accordance with the values developed in the academic world.

c. Building a harmonious connection with family and society in playing the responsibility of character education together.

From an early age, the younger generation needs to be introduced to various positive behaviors including trustworthy behavior, responsibility, attention, dislike of prejudice, often do good deeds, able to control themselves when angry and disappointed, can handle disputes, can work with friends, not likes to bully, is polite and can respect others, wants to hear other people's opinions, understands other people's feelings, can respect himself, knows how to ask for help, is fair, acts as a good friend, can say "no" to invitations that are not good, can resolve disputes and so on.

Of course, a series of these behaviors, must be introduced gradually and practiced in everyday life. Good results from "character building" are designed to be given to the younger generation who have started to socialize a lot both internally on campus and externally with parties outside campus. In connection with this, the campus should consistently apply it to students who are psychologically considered to have understood the meaning socialize. The curriculum is implemented in stages and is planned when leaving the academic bench, and all aspects of character building have been completed including the evaluation in it.

\section{b. Forms of Character Education}

Building character through character education has three basic components, namely "moral knowing or knowledge of morals, moral feeling or feelings about morals, and moral action, or moral actions".In addition to the needs mentioned above, in maintaining the mental development and character of the young generation to remain good, all parents should be able to create conducive family or household conditions, within the family, have time together in the family, have good communication between members. family, respect for each other, have unity and integrity, be able to resolve family crises, and always maintain and pay attention to the 
child's social environment and the school environment as well and it is the parents who do it.Character education is one of the strategies that need to be implemented in learning activities on the academic bench to To reduce the various problems faced by the younger generation, there are 6 pillars of character that need to be developed including:

1) Trustworthiness, a form of character that makes a person of integrity, honest and loyal.

2) Fairness, a form of character that makes a person have an open mind and does not like to take advantage of others.

3) Caring, a form of character that makes a person have a caring attitude and concern for others and the social conditions of the surrounding environment.

4) Respect, a form of character that makes someone always respect and respect others.

5) Citizenship, a form of character that makes a person aware of laws and regulations and care about the natural environment.

6) Responsibility, a form of character that makes a person responsible, disciplined, and always doing things as well as possible.

Honesty means that a student is required to have sportsmanship and honesty towards each other and towards science, loyalty is a form of solidarity and obedience to the norms and values that apply where he lives, respect means being able to appreciate and accept different views, love means having compassion and Compassionate, unselfish means thinking only for their own personal interests, kind and friendly means being kind to others friends and has a high attitude of social solidarity, loyalty and purity, has an attitude of justice and compassion.Building the character of the millennial generation in the era of the Industrial Revolution 5.0 which is full of super-fast technology will bring significant changes, one of which is the education system in Indonesia. Changes in the education system will certainly have an impact on the role of lecturers as educators [16]. Lecturers are required to have high competence to produce students who are able to answer the challenges of the Industrial Revolution 5.0 [17].That it is now entering the transition phase of leaving the 4th industrial revolution, in real terms, the 5th industrial revolution or Industry 5.0 has already started. During Industry 4.0, all emphasized the digital revolution in the form of cyber physical.

Therefore, in the 5th industrial revolution, the character of the emphasis is more on the role of humans as the center of civilization that utilizes digital technology as a means of life in various fields. Thus, Industry 5.0 emphasizes not only machine-tomachine relations and robotic effectiveness, but also human-to-machine and vice versa. For example, in Japan, where the population will be dominated by elderly people from the 5.0 society sect, digital technology services are intended for health services for the elderly, as well as the role of machines in moving public infrastructure, monitoring highway and railway canal facilities, underwater tunnels.Indonesia has no other choice 
but to continue developing digital infrastructure, making policies and regulations that encourage the growth of an efficient and progressive telecommunications industry. In addition, digital cross-platform collaboration must be realized. Likewise, the government also needs to continue systemically to produce digital human resources, creating a digital ecosystem. In the telecommunications and digital industries, it is relatively impossible to run optimally without collaboration and digital sharing.

For example, the telecommunications industry as a network and internet access provider must have a mutualistic symbiosis with an over the top platform, whether it is engaged in e-commerce, communication platforms, video conferencing, streaming, as well as content providers and social media content. In the context of improving the morals and morals of the next generation in this era of globalization, it requires us to strive for the application of Pancasila values on campus, so that future generations of the nation will still be able to live and practice them. And, these noble values remain the guidelines of the Indonesian nation for all time [18]. Applying Pancasila in everyday life, one of the positions of Pancasila for the Indonesian people is as a way of life for the nation. That is, it contains the understanding and understanding that the values of Pancasila are the foundation or guide in regulating attitudes and behaviors that serve as guidelines. The entire Indonesian nation must live and practice the values of Pancasila correctly. If it is not practiced, then the philosophical values of this view of life are not useful at all in everyday life. In a condition that Thus, the Indonesian people will be easily exploited by certain parties so that there will be divisions.

Therefore, the five points contained in Pancasila can be applied by:

a. Having one religion and practicing worship of that religion followed by piety to God and not forcing someone to enter a religion that is believed to be because everyone has the right to choose a religion as desired.

b. Appreciate differences in society which consists of many ethnic groups, religions, races. As well as maintaining etiquette and courtesy, manners in various conditions.

c. Love for the homeland to maintain unity and integrity in the community because we realize that we have one homeland, Indonesia and increase the creativity of the work we produce.

d. Supervise and provide advice on the implementation of people's sovereignty by the government and prioritize decision-making by deliberation and consensus to resolve a problem, whether in the interests of two or more people.

e. Always trying to help others who are in trouble, respecting the results of the deliberation even if it is against our opinion, and daring to fight for justice both for ourselves and for others.

The noble values of Pancasila from the past until now have never changed. Still, the application of Pancasila values has begun to fade due to advances in science, technology, and globalization. Suppose one of the values of Pancasila is applied. In that case, the importance of the other precepts will also be implemented because the 
principles have a strong relationship with each other. It functions as a filter to filter out bad influences from outside so that they do not enter into everyday life, especially the nation's generation. Who live in the millennial era.Therefore, the implementation of Pancasila values should be limited to political discourse or rhetoric. It is necessary to exemplify the nation's leaders and community leaders in actualizing the values of Pancasila. One of them is using Pancasila as a way of life and guidelines for behavior. Leaders of the nation must implement the values of Pancasila in everyday life. Decision-making and planning of government programs must also reflect the values of Pancasila.The character values applied are adjusted to the essential competencies to be achieved in each lesson. In addition, these character values are also used to discuss the latest issues developing in society from the point of view of Pancasila. So that students will get used to seeing, analyzing, responding, and acting by the character values in Pancasila towards an issue or phenomenon around it. That way, students can continue to follow the development of globalization but still be able to maintain the values in Pancasila

\section{CONCLUSION}

Building the character of the millennial generation in the 5.0 revolution era to realize national unity and integrity needs to be prepared systematically so that all levels of the younger generation are not easily exposed to bad behavior due to environmental influences, more exposed to the systematic efforts of other parties to shake the ideological values of the Indonesian nation, namely Pancasila. The exposure of the younger generation to ideologies other than Pancasila will collapse the country. The Tough Generation is the generation that is ready to accept the leadership relay based on Pancasila and the 1945 Constitution of the Republic of Indonesia.

\section{REFERENCES}

[1] J. M. van der Kroef, "The Term Indonesia: Its Origin and Usage," Journal of the American Oriental Society, vol. 71, no. 3, 1951, doi: 10.2307/595186.

[2] BPS, "Sensus Penduduk 2010 - Penduduk Menurut Wilayah dan Agama yang Dianut," Badan Pusat Statistik, 2010. .

[3] A. Y. Sari and F. Rofiyarti, "Penerapan Disiplin Sebagai Bentuk Pembinaan Pendidikan Karakter terhadap Anak Usia Dini," pedagogi, vol. 3, no. 3c, 2017.

[4] A. Susilo and I. Isbandiyah, "Peran Guru Sejarah dalam Pembentukan Pendidikan Karakter Anak Era Globalisasi," Indonesian Journal of Social Science Education (IJSSE), vol. 1, no. 2, 2019.

[5] H. Purnomo, "Peran Orang Tua dalam Optimalisasi Tumbuh Kembang Anak untuk Membangun Karakter Anak Usia Dini,” Prosiding Seminar Nasional Parenting, 2013.

[6] J. Indrastoeti, "Penanaman Nilai-Nilai Karakter Melalui Implementasi Pendidikan Karakter Di Sekolah Dasar," Proasding Seminar Nasional Inovasi Pendidikan Inovasi Pembelajaran Berbasis Karakter dalam Menghadapi Masyarakat Ekonomi Asean, 2016.

[7] M. I. M. Nurhaidah, "Dampak Pengaruh Globalisasi Bagi Kehidupan Bangsa 
Indonesia," Pesona Dasar (Jurnal Pendidikan Dasar dan Humaniora), vol. 1, no. 4, 2015, doi: 10.24815/pear.v7i2.14753.

[8] Setyaningsih, "Dampak Globalisasi Terhadap Generasi Muda," STHD Jateng, vol. 148, 2019.

[9] M. I. M. Nurhaidah, "Dampak Globalisasi Bagi Kehidupan Bangsa Indonesia,” Jurnal Pesona Dasar, vol. 3, no. 3, 2015.

[10] S. Adawiyah, "Pentingnya Pendidikan Karakter pada Anak," Seminar dan Diskusi Nasional Pendidikan Dasar "Menyongsong Transformasi Pendidikan Abad 21, ” vol. 2, no. April 2020, 2018.

[11] D. Yanto, "PENGAMALAN NILAI-NILAI PANCASILA SEBAGAI PANDANGAN HIDUP DALAM KEHIDUPAN SEHARI-HARI,” ITTIHAD, vol. 14, no. 25, 2016, doi: 10.18592/ittihad.v14i25.860.

[12] Aini Shifana Savitri and Dinie Anggraeni Dewi, "Implementasi Nilai - Nilai Pancasila dalam Kehidupan di Era Globalisasi," INVENTA, vol. 5, no. 2, 2021, doi: 10.36456/inventa.5.2.a3549.

[13] D. J. Wardana, A. Handayani, A. R. Rahim, S. Sukaris, and N. Fauziyah, "SOSIALISASI PENTINGNYA NILAI-NILAI PANCASILA," DedikasiMU(Journal of Community Service), vol. 3, no. 1, 2021, doi: 10.30587/dedikasimu.v3i1.2357.

[14] A. A. Agus, "Relevansi Pancasila Sebagai Ideologi Terbuka Di Era Reformasi," Jurnal Office, vol. 2, no. 2, 2016.

[15] Suyadi, Strategi Pembelajaran Pendidikan Karakter. Bandung: Remaja Rosda Karya, 2015.

[16] K. A. Winata, T. Sudrajat, Y. Yuniarsih, and Q. Y. Zaqiah, "Peran Dosen dalam Pembelajaran Pendidikan Pancasila dan Kewarganegaraan untuk Mendukung Program Moderasi Beragama," Jurnal Pendidikan, vol. 8, no. 2, 2020, doi: 10.36232/pendidikan.v8i2.449.

[17] I. Royani, "Peningkatan Kompetensi Guru Menuju Era Revolusi Industri 5.0," Prosiding seminar nasional pendidikan program pascasarjana universitas pgri palembang 10 januari 2020, 2020.

[18] H. S. I. Hidayat, "Implementasi Nilai-Nilai Pancasila Di Perguruan Tinggi Melalui Pemberian Mata Kuliah Pendidikan Bela Negara," The British Journal of Psychiatry, vol. 112, no. 483, 1966. 